SeCond SCIentific Conference

\title{
NATURAL ENVIRONMENT AND DEVELOPMENT
}

SePteMBER, 25-26 2018

LODZ, POLAND

ABSTRACT BOOK

DOI 10.18778/8142-413-4.01 
CONFERENCE ORGANIZER

\section{FACULTY}

OF ECONOMICS AND SOCIOLOGY

University of Lodz

\section{PARTNERS}

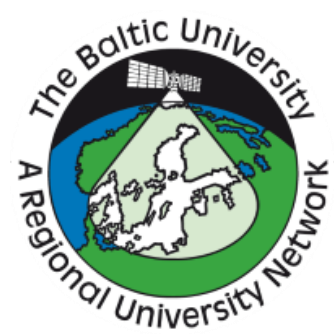

Polskie Stowarzyszenie

Ekonomistów Środowiska

i Zasobów Naturalnych

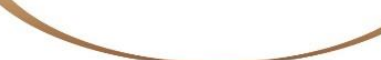

Akademia Sztuk Pięknych

im. Władysława Strzemińskiego w Łodzi 
TYPESETTING

Tomasz Legiędź

DOI 10.18778/8142-413-4.01

e-ISBN 978-83-8142-413-4

Lodz 2018

Wydawnictwo Uniwersytetu Łódzkiego 90-131 Łódź, ul. Lindleya 8 www.wydawnictwo.uni.lodz.pl e-mail:ksiegarnia@uni.lodz.pl tel. (42) 6655863 


\section{SCIENTIFIC COUNCIL}

professor Tadeusz Borys

professor Elżbieta Broniewicz

professor Adam Budnikowski

professor Stanisław Czaja

professor Józefa Famielec

professor Bogusław Fiedor

professor Kazimierz Górka

professor Andrzej Graczyk

professor Barbara Kryk

professor Jakub Kronenberg

professor Aleksandra Kuzior

professor Elżbieta Lorek

professor Krzysztof Malik

professor Piotr Małecki

doctor Marcin Mielczarek

professor Rafał Miłaszewski

professor Aleksandra Nowakowska

professor Barbara Pawłowska

professor Ryszard Piasecki

professor Łukasz Popławski

professor Bazyli Poskrobko

professor Leszek Preisner

professor Maciej Zalewski

professor Tomasz Żylicz 


\section{CONTENTS}

International Horticultural Exhibitions \& Benefits

Pinar Acar

An Attempt at Economic Valuation of Environmental Value by the Method of Travel Costs Hanna Adamska, Stanisław Minta

Sustainability Development at University by Student Involvement in USRA

Aldona Augustiniene, Audrone Daubariene, Gintare Edintaite

The benefits of using renewable energy on the example of biogas plants

Paweł Bartoszczuk

The idea of sustainable neighbourhood in theory and practice

Anna Bernaciak

Participatory budgeting - a tool of citizen involvement and environmental improvements

in Poland: spatial diversity in the east/west configuration

Arnold Bernaciak

The review of indicators representing the accessibility and attractiveness of urban green spaces: why accessible and attractive does not always mean the same?

Magdalena Biernacka

The Goal 12 and the basic questions of economics

Małgorzata Burchard-Dziubińska

Meadow translocation from the airport build up area to the abandoned post-mining land: conservation - reclamation joint venture

Dominika Chmolowska

Energy utilization of waste from the sugar industry

Aleksandra Chuda

Influence of pro-ecological projects financed by EU on shaping regional development

- example of Poland

Agnieszka Dembicka-Niemiec

Integrated spatial planning as an instrument to improve water management processes

on the example of the Lodz Metropolitan Area

Dominik Drzazga

Economic aspects of environmental flows implementation

Anna Dubel, Izabela Godyń

Risk estimation and sources of risk and uncertainty in water management

Anna Dubel, Tomasz Walczykiewicz

Sustainable development natural barriers in economic terms

Andrzej Graczyk

The determinants of the development of the eco-industry in the european countries

Maria Kaczmarczyk

Balanced lifestyle among academic youth

Lidia Kłos

The importance of functional traits in studies on the relationships between diversity and the functioning of the city's ecosystem

Agnieszka Kompała-Bqba, Robert Hanczaruk, Jolanta Luźniak, Wojciech Bqaba

Anthropogenic transformations of river valleys and ecosystem services and standard

of living of inhabitants of riverside areas on the example of the Kłodnica valley

Agnieszka Kompała-Bq̨ba, Robert Hanczaruk, Jolanta Luźniak 
Environmental justice in the context of urban green space availability

Karolina Koprowska

Evaluation of investments in waste management infrastructure

Waldemar Kozłowski

Educational goal of Agenda 2030 and sustainable development

Barbara Kryk

Circular Economy - Challenges for Enterprises

Kamil Kwiecień

Green public procurements in the practice of Lodz City

Tomasz Jakubiec

Smart Specialization of the Opolskie Voivodeship (Life and Environmental Science)

in the Context of Municipalities and Enterprises' Initiatives for Persons Aged 50+

Paulina Legutko-Kobus, Ewa Jastrzębska

Mechanisms of Organizations' Resilience to Weather Extremes - Empirical Study

Agnieszka Leszczyńska

Is optimisation of the objectives of the Helsinki Convention on the reduction

of nutrient loads possible?

Małgorzata Loga

The circular economy in sustainable water management - theory and practice Elżbieta Lorek, Agnieszka Lorek

Development fees for placing the waste in a landfill and their impact on the municipal

waste management

Piotr Małecki

Effective water management as an important element of adaptation to climate change in Polish cities

Dorota Michalak

Protection of Valuable Spaces, Local Cultural Heritage for Sustainable Development

- The case of cultural parks in the Lodz region Justyna Michalak, Ewa Boryczka, Piotr Rzeńca

Activity of the Use and Water Protection Economics Section of the Polish Association of

Environmental Economists and Natural Resources Rafał Miłaszewski

The spatial distribution of the JESSICA projects implemented in Polish municipalities Karol Mrozik

Low-Emission Economy Plans - Planning and Implementation Dilemmas.

The case of cities of the Lodz Metropolitan Area

Rafat Mysiala, Agnieszka Rzeńca

Sewage Treatment Plant Location Choice in Rural Commune by AHP Method Katarzyna Oszczapińska, Iwona Skoczko

Evaluation of Ecosystem Services on $\mathrm{CO}^{2}$ Absorption for the Regional Development Alla Pakina

The Level of Eco-Innovations in the EU Member States Jolanta Pakulska

Ecological Innovations as an Element of the Organization Strategy Jolanta Pakulska, Małgorzata Rutkowska

Comparison of water footprint of Poland and Ukraine 
Impact of rivalry and excludability on Individual Social Responsibility in the context of transport behaviour

Monika Paradowska

Benefits of including the concept of corporate social responsibility

in the strategy of transport sector companies

Barbara Pawłowska

Impact of natural and anthropogenic factors on the water resources

of the Wielkopolsko-Kujawski Lake District

Adam Piasecki

Production of phosphate fertilizers - comparison of the conventional method with

the Best Available Technique (BAT)

Katarzyna Pieklarz

The Concept of a Climate Resilient Economy from the Perspective of Local Communities Dariusz Pieńkowski, Wojciech Zbaraszewski

Non-renewable natural resources as the key factor in civilizational development Tadeusz Pindór

Determinants of the circular economy development for plastics Krzysztof Posłuszny

Directions of using municipal sewage sludge in the European Union

- conclusions from the analysis of statistical data

Ksymena Rosiek

Insurance awareness in the field of weather risks

Eleonora Ratowska-Dziobiak

All for one and one for all? External effects of water supply as provisioning

service of ecosystems

Małgorzata Stępniewska, Andrzej Mizgajski

Environmental education vs. punishment - an issue of protection of environment

Diana Szwejser

Ecological modernization - the issue of efficiency

Paulina Szyja

Circulation of matter in the natural and anthropocentric perspective

Jerzy Śleszyński

The development of road transport - opportunities and threats to the environment

and society

Mariusz Trela

The impact of energy consumption, foreign direct investment, trade openness, corruption, and GDP on carbon dioxide emissions in Poland

Dorota Wawrzyniak

Causes and extent of soil acidification resulting from agricultural activity

- thoughts in the context of good agricultural practice

Mirosława Witkowska-Dąrowska

Foreign Direct Investment and the Environment

Michał Wojtaszek

How important urban and post-industrial habitats are for ecosystem services?

Gabriela Woźniak, Edyta Sierka, Agnieszka Błońska, Wojciech Bierza, Teresa Nowak, Agnieszka Kompała-Baba, Anne Wheeler 
The „Eco” Philosophy in Visual Communication Design - Visible / Invisible Signs, intuition / impression / perception

Anna Wrzesień

When tree stands can be cut? - case study of carbon accumulation and timber production

Emilia Wysocka-Fijorek

Forestry Social Responsibility Concept

68

Emilia Wysocka-Fijorek, Piotr Komorowski

The possibility of using considered a weed Impatiens parviflora DC. as a source

of valuable antioxidants

Joanna Zielonka-Brzezicka, Anna Nowak, Adam Klimowicz, Magdalena Tkacz, Danuta Martyniuk 
DOI 10.18778/8142-413-4.01

International Horticultural Exhibitions \& Benefits

PINAR ACAR

Green Cities Consultancy Co. Co-Founder \& General Manager AIPH Consultant e-mail: pinar.acar@greencities.com.tr

\begin{abstract}
An Expo is a global event that aims at educating the public, sharing innovation, promoting progress and fostering cooperation. It is organized by a host country that invites other countries, companies, international organizations, private sector, NGOs and the general public to participate. Due to the diversity of its participants, from top decision makers to children, Expos offer a multifaceted event where extraordinary exhibitions, diplomatic encounters, business meetings, public debates and live shows take place at the same time.

An international horticultural exhibition is a development project. It is able to fascinate large numbers of people and generate demand for site consumptions of goods and services. The exhibition also has the potential to increase tourism and horticulture sectors' revenues. The expo is not an end in itself, it is an accelerator. An expo's planning and the vision of its organizers should include not only the period leading up to opening day and the organization itself, but also the years beyond closing day during which continuing goals can be comprehended. The organizers should determine those goals and how they will be reached with the expo as their origin. These achievements called as "Legacy" of the exhibition.
\end{abstract}




\title{
An Attempt at Economic Valuation of Environmental Value by the Method of Travel Costs
}

HANNA ADAMSKA

Wrocław University of Environmental and Life Sciences e-mail: hanna.adamska@upwr.edu.pl

STANISŁAW MINTA

Wrocław University of Environmental and Life Sciences e-mail: stanislaw.minta@upwr.edu.pl

\begin{abstract}
The natural environment is the basis of human existence. It provides many components used in consumption and production processes that affect health, life and social well-being. The environment, being a public good, should be protected and its value should be estimated. The help in this area is the valuation of the value of the natural environment by analyzing the costs and benefits.

The study attempts to evaluate the value of the natural environment of Góra Zamkowa, which is part of the landscape park "Orle Gniazda". For this purpose, the travel cost method was used, which was based on the results of the survey. The results obtained based on the respondents' opinions indicate a measurable value of the analyzed object. The individual respondents' opinions varied, which resulted from two factors: frequency of visits and the coefficient of travel costs.
\end{abstract}




\title{
Sustainability Development at University by Student Involvement in USRA
}

\author{
ALDONA AUGUSTINIENE \\ Kaunas University of Technology \\ e-mail: aldona.augustiniene@ktu.It \\ AUDRONE DAUBARIENE \\ Kaunas University of Technology \\ GINTARE EDINTAITE \\ Kaunas University of Technology \\ e-mail: gintare.edintaite@ktu.It
}

\begin{abstract}
The paper presents a case of sustainability development at Kaunas University of Technology by student involvement in the university social responsibility audit (USRA) carried out within a framework of Erasmus+ project "Certification in Social Responsibility Audit, CertSRA".

The methods used for collecting research data were as follows: analysis of scientific literature, document content analysis, structured written reflection of students. The methods employed for data analysis were descriptive qualitative content analysis and manifest analysis of document content.

Research findings show an increased student ability to identify problems and resources of the university social responsibility (USR) and gained knowledge about social audit. Moreover, the participants emphasized the value of experiential learning and team-building skills developed in the process of training and social responsibility auditing.
\end{abstract}


The benefits of using renewable energy on the example of biogas plants

PAWEt BARTOSZCZUK

Warsaw School of Economics e-mail: pabartosz@gmail.com

\begin{abstract}
In view of the expected development of renewable energy sources in the country, an important goal is to apply solutions, using innovative technologies that will ensure the stability of the power system. It is important to recognize not only the conditions and opportunities for the development of energy sources, but also the economic and ecological aspects of their development. Apart from the positive environmental impact of renewable energy sources, their economic profitability is very important. The profitability of using a biogas plant has been presented.
\end{abstract}


The idea of sustainable neighbourhood in theory and practice

ANNA BERNACIAK

Poznań University of Economics and Business e-mail: anna.bernaciak@ue.poznan.pl

\begin{abstract}
In 2007, in the Urban Development Problems, H. Zaniewska presented historical trends in shaping housing environment, postulating the need to look at the housing estate in the context of meeting sustainability criteria. Almost 30 years earlier, T. Sumień and A. Wegner-Sumień published detailed guidelines on urban tissue design "'in an ecological context"". Currently, more than 10 years from the first of these publications and almost 40 from the second one, there is still a discussion about the need to plan the housing environment in accordance with the principles of sustainable development, taking into account contemporary global trends. However, practice indicates that these ideas often remain in the declarative sphere or are treated selectively.

In this study, the author points to contemporary postulates of shaping balanced districts / neighbourhoods, referring to historical assumptions. She also tries to verify the state of selected urban planning ideas in the context of the principles of sustainable development, using selected tools for the evaluation of the housing environment.
\end{abstract}

As a result of the conducted research, she formulates the thesis that the analysed housing estates built before 1989 meet the contemporary assumptions of a balanced district greater than the analysed projects created in the last 10 years. 


\title{
Participatory budgeting - a tool of citizen involvement and environmental improvements in Poland: spatial diversity in the east/west configuration
}

\author{
ARNOLD BERNACIAK \\ WSB University in Poznan \\ e-mail: arnold.bernaciak@wsb.poznan.pl
}

\begin{abstract}
Participatory budgeting is a relatively new tool of local public financial management. The concept and features of the participatory budgeting allow perceiving it as a tool of implementation of the rules of sustainable development also. The most important of these features are: citizen involvement, participation of citizens in the process of decision making, focusing on the real, local problem. The participatory budgeting can also be seen as an indicator of public involvement in local problems solving and the importance that residents attach to environmental issues.

The research problem comes down to the question about the level of diversity of participatory budgeting between the eastern, central and western Polish communes. There are questions about the differences in sizes of budgets, voter turnout, total number of submitted and selected projects and number of projects connected with environmental improvements.
\end{abstract}

The main goal of the paper is an attempt to construct models of communes implementing a participatory budget. There are one general and three regional models: for eastern, central and western Poland communes. The second goal is the identification of differences in the scale and types of green project leading to environmental improvements in communes.

The research is conducted in communes of three agglomerations: Białystok (eastern Poland), Łódź (central Poland) and Poznan (western Poland).

All the necessary information has been obtained from municipal offices and public statistic. Participatory budgeting voted in 2017 and implemented in 2018 were taken into account. Basic statistic methods were used for analysis and tests.

The most important findings allow stating, that there are quite big differences between eastern and western part of Poland if it comes to the number of implemented participatory budgeting and amount of money intended for. This indicates the needs and opportunities for the flow of knowledge and exchange of experiences in this area between individual parts of the country and between particular local governments. 
The review of indicators representing the accessibility and attractiveness of urban green spaces: why accessible and attractive does not always mean the same?

\author{
MAGDALENA BIERNACKA \\ University of Lodz \\ e-mail: magdalena.biernacka@uni.lodz.pl
}

\begin{abstract}
One of the Significant Sustainable Development Goals promoted by the UN, as well in other international declarations and documents (WHO, European Union) is to ensure: "universal access to safe, public green spaces". In connection with this goal, different researchers, as well as decision makers in many cities decided to construct measures of access to green spaces. The most popular measure is 15 minutes walking distance from the place of residence to the nearest green space (of minimum $2 \mathrm{ha}$ ), and also that the nearest green space should be no further than $300 \mathrm{~m}$ from the place of residence. There are many indicators in the literature on access to green spaces, they take into account various aspects such as: distance, surface of green space, amount of green space per capita, its attractiveness (cleanliness, equipment, biodiversity), as well as perception and psychological sense of access to these spaces (safety, congestion). There are a number of such indicators and the accessibility of green spaces and their attractiveness is understood in a variety of ways, with additional ambiguity related to other terms, such as distribution. The main goal of this article is to present various indicators of access to green spaces in the literature. The analysis will mainly cover English-language literature, in the search for examples of indicators used for research purposes as well as in planning documents in various cities. This will be a review article comparing existing measures and synthesizing current knowledge related to broadly understood access to public and private green spaces.
\end{abstract}


The Goal 12 and the basic questions of economics

\author{
MAŁGORZATA BURCHARD-DZIUBIŃSKA \\ University of Lodz \\ e-mail: malgorzata.burchard@uni.lodz.pl
}

\begin{abstract}
The Goal 12 of the 2030 Agenda entitled Responsible consumption and production is the central point of considerations in the paper. By seeking answers to three basic questions of economics: What?, How? and For whom to produce? an attempt was made to demonstrate that achieving this goal can only be conducted through deliberate and consistent implementation of other social, political and environmental goals.

Without a deep correction of consumption and production behaviors identification of the Goal 12 will be an idle procedure. If we limit the criteria for assessing its implementation to the issues of production and availability of food, energy and water, as is currently the case, we lose the wider context associated with the rapid growth of many markets. Data on food markets, mobile devices and military equipment markets served to illustrate the problems we face in the development of sustainable consumption and production. The common feature of these markets is their size. On the first market all people co-create the demand side, and on the second there are almost all (though some of them appear on it many times).
\end{abstract}

The third market, due to the generally destructive nature of its products, develops against common sense, which suggests that it would be possible to use those resources of labor, nature and capital in a more constructive way. It is necessary to rationalize the directions of spending financial resources, and not only to change the consumption habits and the behavior of producers. The State plays a very important role in this field as an entity responsible for generating a huge demand for various goods and services through the public procurement system. The lack of provisions regarding the potential benefits of shifting funds from activities which are destructive in nature, to development, protection and adaptation purposes is the weakness of the 2030 Agenda. 
Meadow translocation from the airport build up area to the abandoned postmining land: conservation - reclamation joint venture

DOMINIKA CHMOLOWSKA

The Institute of Systematics and Evolution of Animals of the Polish Academy of Sciences e-mail: chmolowska@isez.pan.krakow.pl

\begin{abstract}
To compensate for the Katowice airport build-up on highly valuable wet meadows, 1.3 hectare of turf were transferred to the reclaimed area in Radzionków in 2013. This was the first case of large vegetation turf translocation in Poland. The transplantation was also unique at the large scale, as the ecosystem salvage was combined with revitalization of degraded land of a receptor place. The receptor place used to be a limestone quarry and calamine post-mining area, which was abandoned decades ago. The project laid bases for setting up a habitat garden facilitated with nature education center which returned this abandoned area for society usage. We monitored plant community composition and soil physico-chemical and microbial properties for three seasons: before the transfer and two years afterwards $(2014,2015)$ in three meadows. Physical disturbances at the time of translocation, oxygenation and presumed habitat drying and humus decomposition at the receptor place resulted in large fluctuation of soil nutrients. Despite weed invasion, meadows maintained their high plant diversity and the dominance of the diagnostic and characteristic meadow species during two first seasons following translocation. Although returning the degraded land for public use is of clear societal benefit, the restored site comprised different habitat properties than the translocated ecosystem, challenging the restoration. Longer period of monitoring is suggested to estimate the success of habitat conservation.
\end{abstract}


Energy utilization of waste from the sugar industry

ALEKSANDRA CHUDA

Lodz University of Technology e-mail: 175283@edu.p.lodz.pl

\begin{abstract}
The development of low - emission economy and limited fossil resources provide the basis of the European bioeconomy model.

The growing prices of plant biomass from dedicated plantations, the anxiety of monocultures, and limitations related to production of first generation biofuels are causes of intensification of research on the development of technologies of second generation biofuels production based on waste lignocellulosic biomass.
\end{abstract}

The development of environmentally friendly and effective methods degradation of the tightly packed lignocellulose structure harmonizes with the growing interest in the establishment of own biogas plants by large agro - food factories.

This approach is related to environmental and economic aspects. Biogas plants enable not only to utilize wastes generated by food processing but also considerably improve the energy balance and allow for economic gain from the sale of green energy.

One third of world sugar production is derived from sugar beets. Beet pulp due to the scale of sugar production is a waste product significant in terms of volume. Approximately 14 million tons of pulp is produced per year in the European Union and 2,38 million tons in Poland. Their management is an important issue not only related to solving problems related to the utilization of waste materials, but also the possibility of acquiring alternative energy sources. Commonly pulp are mainly used as feed for ruminants, but due to a significant number of them all over the world looking for new solutions to the management of this waste. High content of polysaccharides: cellulose, hemicellulose, pectin makes them an attractive source for obtaining valuable semi - products used in the food, chemical and biotechnology industries.

In conducted research was to determine the effect of different sugar beet pulp (SBP) pretreatments on biogas yield from anaerobic digestion. SBP was subjected to grinding, thermal - pressure processing, enzymatic hydrolysis or combination of these pretreatments. It was observed that grinding of SBP to $2,5-\mathrm{mm}$ particles resulted in the cumulative biogas productivity of $617,2 \mathrm{~mL} / \mathrm{g}$ volatile solids (VS), which was $20,2 \%$ higher compared to the biogas yield from the not pretreated SBP and comparable to that from not ground, enzymatically hydrolyzed SBP. The highest cumulative biogas productivity $898,7 \mathrm{~mL} / \mathrm{g}$ VS was obtained from the ground, thermal - pressure pretreated and enzymatically hydrolyzed SBP. 
Influence of pro-ecological projects financed by EU on shaping regional
development - example of Poland

AgniesZKa DembickA-NiemieC

Uniwersytet Opolski e-mail: dembicka.uni@wp.pl

\begin{abstract}
According to assumptions of the strategic paper of the European Union a Strategy Europe 2020, towards Member States assigned objectives stayed as part of the conducted development policy. At the same time Poland as one of beneficiaries of operational programmes, the EU is receiving the financial assistance, carrying out a project for the circle, of low-emission economy and more widely of sustainable development. It's important to estimate action which are carried out in this, and it's influence on the development of individual regions. Identifying the influence of projects about character is a purpose of the article pro-ecological to the development of provinces of Poland. Initiatives realized as part of operational programmes in the programming period were analysed 2014-2020. Moreover, levels of development of provinces of Poland were determined in chosen years.
\end{abstract}

Author applied taxonomical research methods (Z. Hellwig) and desk research which was helpful to analysis of projects carried out. 
Integrated spatial planning as an instrument to improve water management processes on the example of the Lodz Metropolitan Area

\author{
DOMINIK DRZAZGA \\ University of Lodz \\ e-mail: dominik.drzazga@uni.lodz.pl
}

\begin{abstract}
One of the effects of the sub-urbanization processes taking place in suburban areas is the increase in building intensity and the decrease of the natural and open areas. This process also causes the loss of water retention capacity and may result in local flooding in areas with intense urbanization. Local territorial self-government units can potentially prevent these problems by proper planning of spatial development, but the protection of land against excessive urbanization of open areas violates the economic interests of landowners, and is not in the political interest of local authorities. For this reason, it seems that effective solution for problems related to the protection of open and biologically active land (which can be treated as a kind of public good - mixed good) from excessive development - is not possible. Solving these retention problems requires management of waters in the catchment and not administrative territorial systems in which local self-government (communities, municipalities) develop spatial plans. This is also due to the lack of local land use plans for the areas sensitive from biological and hydrological perspective. Water management therefore requires a functional approach to planning of spatial development, as well as introducing the possibility of protecting biologically active and open areas (important for water retention) at the level of regional planning, by directing binding, regulatory arrangements to local plans.
\end{abstract}


Economic aspects of environmental flows implementation

ANNA DUBEL

AGH University of Science and Technology e-mail: adubel@zarz.agh.edu.pl

IZABELA GODYŃ

Cracow University of Technology e-mail: Izabela.Godyn@iigw.pk.edu.pl

\begin{abstract}
Sustainable management of water resources requires leaving in the rivers a flow that ensures biological life. Since 2014, water authorities have been seeking to develop a methodology for determining environmental flows that are to reflect the inherently time-changing environmental water needs. Environmental flows have aroused much controversy because for many rivers in Poland, they proved to be significantly higher than the previously used intact flows, which results in limited disposable resources in rivers, which may translate into limitation of existing water permits for water abstraction.

The paper will present economic aspects of the implementation of environmental flows that will undoubtedly bring environmental benefits from providing the necessary amount of water for aquatic ecosystems as well as for water dependent ecosystems. However, on the other hand, they can cause significant costs for existing water users and limitations in economic use of water resources in the future. A case study of the Raba catchment will serve for presentation of the costs and benefits as well as the methods to estimate them.
\end{abstract}




\title{
Risk estimation and sources of risk and uncertainty in water management
}

ANNA DUBEL

AGH University of Science and Technology e-mail: adubel@zarz.agh.edu.pl

TOMASZ WALCZYKIEWICZ

The Institute of Meteorology and Water Management, National Research Institute

\begin{abstract}
The aim of the paper is to identify sources of risk and uncertainty in water management in order to include them in a rigorous way in the decision making in water management according to the IWRM principles. The scientific literature review as well as the case studies analysis served for the identification of main features and challenges related to the risk and uncertainty estimation in water management. The conclusions indicate the gaps in the current practice of risk estimation, presentation and visualization as well as the ideas for the improvements with this regard. Thus, in turn could enhance decision making in water management.
\end{abstract}


Sustainable development natural barriers in economic terms

ANDRZEJ GRACZYK

Wrocław University of Economics e-mail: andrzej.graczyk@ue.wroc.pl

\begin{abstract}
In sustainable development, the natural component does not have a constant readiness to develop. Its distinguishing feature is the duration and ensuring the balance. The use of natural resources and forces of nature can therefore be a source of barriers to sustainable development. In economic terms, the barriers can be described as resource, price, structural and efficiency barriers. Barriers are analyzed from two perspectives. In macroeconomic terms, they influence the dynamics and directions of sustainable development. In microeconomic terms, they cause changes in the selection of production factors, changes in the structure of production and consumption as well as changes in the efficiency of production and consumption utility.
\end{abstract}


The determinants of the development of the eco-industry in the european countries

\author{
MARIA KACZMARCZYK \\ University of Lodz \\ e-mail: mariacharzynska@wp.pl
}

\begin{abstract}
The article discusses the current, rarely discussed in the Polish literature development of a relatively young innovative sector of the products and services serving for the environmental protection. These are the products and activities contributing to the improvement of the natural environment by limiting pollutant emissions, waste generation and consumption of the raw materials in the production processes. The paper discusses the origin of the eco-industry, the current conditions of its functioning and determinants of the development of the newest branches in the environmental protection goods and services sector. The determinants were divided into institutional-political, organizational and strategic-tactical. The article verifies the hypothesis that the economies most advanced in terms of production of the eco-industry sector also have convergent institutional determinants of the development in this field of their economies.
\end{abstract}


Balanced lifestyle among academic youth

\author{
LIDIA KŁOS \\ University of Szczecin \\ e-mail: klosl@wneiz.pl
}

\begin{abstract}
An aim of this article is to define a balanced lifestyle and VS conception and also to interpret a functioning youth's lifestyle. For this purpose was conducted a life balance test that will allow to point out essential components of balance between private life and professional life or university life of our respondents.

The surveys were done on Steering Group of 104 students of third year of undergraduate full-time and external studies in 2017-2018. An analysis of the main components was used to explain the research.
\end{abstract}

The conclusions about balanced lifestyle of academic youth will be enunciated based on received results. 
The importance of functional traits in studies on the relationships between diversity and the functioning of the city's ecosystem

AGNIESZKA KOMPAŁA-BĄBA

University of Silesia in Katowice e-mail: agnieszka.kompala-baba@us.edu.pl

ROBERT HANCZARUK

University of Silesia in Katowice e-mail: roberthanczaruk@gmail.com

JOLANTA LUŹNIAK

University of Silesia in Katowice

WOJCIECH BĄBA

University of Silesia in Katowice

\begin{abstract}
The relationship between functional diversity and the functioning of urban ecosystems is an extremely important research topic in recent times. A set of traits related to persistence, dispersal and regeneration play a crucial role and decide how a given species reacts to changes in the environment and how these relationships affect ecosystem functions or ecosystem services. Vegetation of ruderal habitats provides a number of such ecosystem services, such as: supporting (soil formation, nutrient and water cycling); regulating services (modification of climatic conditions, phytoremediation, protection against erosion and weather extremes, pollination), cultural (aesthetic, landscape, educational, recreational ones and ecotourism). Therefore, it is important that this vegetation should be taken into account and kept in spatial planning and land management plants in cities in accordance with the principles of sustainable development.
\end{abstract}


Anthropogenic transformations of river valleys and ecosystem services and standard of living of inhabitants of riverside areas on the example of the Kłodnica valley

\title{
AGNIESZKA KOMPAŁA-BĄBA
}

\author{
University of Silesia in Katowice \\ e-mail: agnieszka.kompala-baba@us.edu.pl \\ ROBERT HANCZARUK \\ University of Silesia in Katowice \\ e-mail: roberthanczaruk@gmail.com \\ JOLANTA LUŹNIAK \\ University of Silesia in Katowice
}

\begin{abstract}
The anthropopressure contributed to the degradation of many river valleys and riverside ecosystems. An example is the Kłodnica valley - the main river of the Upper Silesian Industrial District. The aim of the research was to determine the impact of anthropogenic transformations of vegetation in the Kłodnica valley on the ecosystem services provided by it, as well as the standard of living of the inhabitants. The vegetation of the semi-natural section (in Katowice) is characterized by high diversity and is represented by aquatic, rush and meadow communities, whereas the anthropogenic section (in Gliwice) is characterised by mainly ruderal and nitrophilous communities. The transformation of the valley landscape, the increase in the frequency of floods and the deterioration of local climatic and habitat conditions mean that the majority (81\%) of Gliwice residents assess the condition of the Kłodnica valley badly, pointing to the need for its revitalization (76\%).
\end{abstract}




\title{
Environmental justice in the context of urban green space availability
}

\author{
KAROLINA KOPROWSKA \\ University of Lodz \\ e-mail: karolina.koprowska@uni.lodz.pl
}

\begin{abstract}
Environmental justice is a term, which includes both exposure to environmental 'bads' as well as access to environmental 'goods', which might be unequally experienced by different socio-economic groups. In other words, environmental justice scholars study whether everybody can have an equal right to healthy, nurturing environment, which supports their development and well-being. Environmental justice movement arose as a response to so called 'environmental racism' in USA, which affected communities of blue-collar workers, people with lower income and of AfroAmerican, Asian, Latin or native origins. Although, initially environmental (in)justice was rooted in racial discrimination in USA, nowadays it encompasses wider range of issues, including problems on a local and global level, from degradation and pollution of natural resources to aspects related to spatial planning. Unequal access to environmental amenities - like green spaces - was not primarily a main scope of a discourse, however it is gaining more attention nowadays, especially in context of urban environment. Urban green areas are an important factor influencing health and well-being of urban residents, but access to them can be uneven in terms of socio-spatial heterogeneity. Raising challenges of living in the cities, related to among others: climate change, densification or sprawling of developments, require sustainable management of green spaces and provision of equal (socially just) access to benefits provided by these areas. Moreover, another important aspect of the discussion is linked to potentially beneficial planning decisions (e.x. increasing availability of urban green spaces) and their long-term consequences, which may eventually lead to gentrification and increased social inequalities (environmental injustice). Complexity of the problem related to availability of green spaces in the cities needs an interdisciplinary approach, which combines ecological, spatial and socio-economic aspects. Following presentation will describe current state-of-the-art in the field of environmental justice, with particular emphasis on green space availability in the context of urban environment.
\end{abstract}


Evaluation of investments in waste management infrastructure

\author{
WALDEMAR KOZ $Ł O W S K I$ \\ University of Warmia and Mazury in Olsztyn \\ e-mail: wkozlowski@xl.wp.pl
}

\begin{abstract}
Municipal waste is waste generated in households, as well as waste from other waste producers, which due to their nature or composition is similar to waste generated in households. The creation and optimization of infrastructure related to waste management has many functions of an economic, environmental and social character.

Effective management of municipal waste should meet two basic requirements: compliance with environmental protection principles and compliance with the principles of material management.

The aim of the article is to evaluate the investment in waste management infrastructure on the example of a project comprising 36 municipalities from the Warmian-Masurian Voivodeship.

The specific objectives are:

- $\quad$ analysis of the amount and composition of waste generated in the studied area,

- development of an indicator model for the assessment of the examined projects,

- $\quad$ strategic analysis of waste management in the long-term perspective.

The basic research methods will be: the method of analysis, the design method, and the statistical method. The study will enable professional analysis of completed and planned infrastructure projects in the field of waste management. The developed assessment model will help decisionmakers to make decisions in planning next projects.
\end{abstract}


Educational goal of Agenda 2030 and sustainable development

BARBARA KRYK

University of Szczecin e-mail: krykb@wneiz.pl

\begin{abstract}
The Millennium Development Goals established by the UNO in 2000 have not been fully achieved. In 2015, they were replaced with Sustainable Development Goals characterized by a significantly wider horizon of planned activities and perspectives by 2030, that are included in the Agenda 2030 document. One of them is goal 4. - inclusive and high-quality education for all and promoting LLL (lifewide lifelong learning), the implementation of which is the condition for many other goals. Therefore the purpose of the presentation is to identify and evaluate Polish achievements in implementing sustainable development in the context of Goal 4 of the 2030 Agenda. The current set of synthetic substantive indicators, established by the UNO, were used to measure the progress of this implementation. The research period covers the period 2010-2016. The methods used are: analysis of legal acts, institutional reports, statistical data, dynamics analysis, index analysis and a 'plus' evaluation scale reflecting the achievements. This allowed for establishing the level of achievement of completion of tasks assigned to Goal 4 and highlighted those that require intensification of actions. The conducted analysis shows that in the scope of Goal 4 Poland has already achieved much. Five out of ten tasks have been completed (4.2, 4.5, 4.7, 4.a, 4.c), and their corresponding monitoring indicators are high with satisfying level of achievements. The levels of achievements measured with indicators corresponding to tasks 4.1 and 4.6 are quite satisfactory. The remaining tasks will be implemented, but it is hard to predict if any spectacular effects will be achieved at this point. To conclude, Poland has a good chance of implementing the majority of tasks under Goal 4 of the 2030 Agenda.
\end{abstract}




\title{
Circular Economy - Challenges for Enterprises
}

\author{
KAMIL KWIECIEŃ
}

Częstochowa University of Technology e-mail: kamilkwiecien94a@gmail.com

\begin{abstract}
Circular economy is an economic concept closely related to the idea of sustainable development. Its main assumption is the use of products, materials and other resources in such a way that they remain in the economy as long as possible. The reduction of waste production also plays an important role. The implementation of the circular economy concept depends to a large extent on the actions taken by enterprises. These activities mainly include areas such as energy efficiency and innovation, product design or re-use of raw materials. The aim of the article is to present the most important challenges faced by business entities in the context of implementing a circular economy.
\end{abstract}




\title{
Green public procurements in the practice of Lodz City
}

\author{
TOMASZ JAKUBIEC \\ Łódź City Hall \\ e-mail: t.jakubiec@uml.lodz.pl
}

\begin{abstract}
Green public procurement is a tool of economic policy which, referring to sustainable development, aims to ensure the quality of life in the long-term perspective, minimizing the negative impact on the environment. These are the rules according to which economic entities incorporate ecological criteria and requirements into the public purchasing process and look for solutions that minimize the negative impact of products / services on the natural environment and take into account the whole life cycle of products. Public institutions, especially local governments, cities, apply green public procurement, primarily in areas where they can obtain comprehensive benefits, both environmental and economic. These are primarily infrastructure investments, water and sewage, road, thermo-modernization and revitalization projects. Good practices in the application of environmental criteria, generating environmental effects and improving the quality of life of residents were presented on the example of the approach to green tender policy and implementation of selected investment projects of the city of Łódź. Considering the diversity of goals and ways of achieving sustainable development that territorial self-governments are dealing with, it can be concluded that the inclusion of GPP criteria opens up new opportunities for obtaining multiple benefits of an economic, social and ecological nature. The implementation of GPP policy may help propagate pro-environmental solutions and influence the dissemination of production and consumption patterns consistent with the principles of sustainable development. This approach is also part of the development of a green economy that uses resources sparingly.
\end{abstract}




\title{
Smart Specialization of the Opolskie Voivodeship (Life and Environmental Science) in the Context of Municipalities and Enterprises' Initiatives for Persons Aged 50+
}

\author{
PAULINA LEGUTKO-KOBUS \\ Warsaw School of Economics \\ e-mail: legutkopl@wp.pl \\ EWA JASTRZĘBSKA \\ Warsaw School of Economics \\ e-mail: ewa.jastrzebska@sgh.waw.pl
}

\begin{abstract}
This article aims to assess the initiatives created for seniors by municipalities and selected enterprises seated in the Opolskie Voivodeship.

The assessment is set against the backdrop of the Opolskie Voivodeship's characteristics in the context of (sustainable) development, smart specialisation (Life and environmental science) and Special Demographic Zone Programme, launched in 2014 the Opole region, as Polish region particularly affected by adverse demographic changes.

The online research was conducted between December 2017 and January 2018 among the Opole region's municipalities and enterprises cooperating with business environment institutions. The research allows to reveal undertook initiatives for seniors (addressing the improvement of quality and accessibility of products and services for elderly people and motivating them to increase their digital literacy) and assess knowledge and implementation of Programme.
\end{abstract}




\title{
Mechanisms of Organizations' Resilience to Weather Extremes - Empirical Study \\ AGNIESZKA LESZCZYŃSKA \\ Maria Curie-Skłodowska University e-mail: agnieszka.leszczynska@poczta.umcs.lublin.pl
}

\begin{abstract}
The ability to resist and respond to an external shock and recover once it has occurred is called resilience. The present paper discusses mechanisms of organizations' resilience to weather extremes. The objective of the study was to determine which mechanisms are applied by European businesses in order to cope with weather extremes. The paper presents the frequency individual mechanisms are applied in and determinants of their employment. Findings are intended to facilitate a better understanding of resilience to weather extremes in organizations.
\end{abstract}


Is optimisation of the objectives of the Helsinki Convention on the reduction of nutrient loads possible?

MAtGORZATA LOGA

Warsaw University of Technology e-mail: malgorzata.loga@pw.edu.pl

\begin{abstract}
New levels of reduction of nutrient loads to the Baltic Sea should be achieved by 2021 by all Baltic States. The basins of four rivers, ie Odra, Vistula, Nemunas and Dvina, are responsible for $44 \%$ and $47 \%$ of the nitrogen and phosphorus load respectively. The BigRivers4Baltic project, which obtained the status of a flagship project for the European Union Strategy for the Baltic Sea Region, aims to prepare tools for simulating the effects of activities in this area in Poland, Lithuania, Latvia, Belarus and partly in Russia and Germany. By using coherent tools to modify water management plans in river basin areas, it will be possible to develop the best river basin solutions for each country and region.

However it is not possible to developed optimal solutions without taking into account costs of their implementation. It remains an open question whether the classical efficiency analysis is a sufficient tool when additional costs related to changes in the production method (eg. agriculture) should be taken into account?
\end{abstract}


The circular economy in sustainable water management - theory and practice

ELŻBIETA LOREK

University of Economics in Katowice e-mail: elzbieta.lorek@ue.katowice.pl

AGNIESZKA LOREK

University of Economics in Katowice e-mail: agnieszka.lorek@ue.katowice.pl

\begin{abstract}
In the article are presented the principles of the circular economy implemented in the water resources management. Special attention was paid to problems in water management in new market conditions, related to the adoption of the new Water Law. The system of financing of new solutions in water management in the light of emerging controversies related to their implementation was discussed. Changes in water management were reviewed in the light of the provisions of the adopted new Water Law and threats resulting from its introduction, especially in the light of the impact on budgets of households and enterprises. Examples of good practices of the implementation of the circular management principles in water ecosystems in the country and around the world were also presented.
\end{abstract}


Development fees for placing the waste in a landfill and their impact on the municipal waste management

PIOTR MAŁECKI

Cracow University of Economics e-mail: maleckip@uek.krakow.pl

\begin{abstract}
The dynamic development of charges for the use of the environment there was in Poland after 1989, since the start of the transformation of the system. Then it introduced, among others, the fee for storage of waste equivalent to the existing waste for waste in a landfill. The rate of those charges related to certain types of waste, m.in. municipal waste, increased in selected years not in proportion to the ratio of inflation - unlike the other charges for the use of the environment. It was, for example, between the years 2008 and 2009, when the rate of charges for unsorted municipal waste increased from 15,71 to 75 polish zlotys per $\mathrm{Mg}$. In the year 2018 bid has been raised 20 polish zlotys over the previous year.

The aim of the article is the answer to the question whether and to what extent the radical increase in the rates for placing the waste in the landfill had an impact on the municipal waste management in the context of the limitations of their mass stored on landfills. In the article the comparative analysis between development fees and volumes of municipal waste going to landfills in the representative period.
\end{abstract}


Effective water management as an important element of adaptation to climate change in Polish cities

\author{
DOROTA MICHALAK \\ University of Lodz \\ e-mail: d.michalak@uni.lodz.pl
}

\title{
ABSTRACT
}

As indicated by the Strategic Plan of Adaptation to Climate Change in Poland (SPA 2020), the one of the sector sensitive to the impact of climate change is "water management". The threat of various forms of flooding occurs practically all over the country. Inappropriate spatial management, in particular investing in threatened areas, including in flood zones of rivers and too low natural retention capacity as well as artificial reservoirs, not only in river valleys, limits effective actions in situations of excess or deficit of surface waters. There is a risk that in the future these phenomena will occur with increased frequency. The scenarios indicate an increased likelihood of flash floods caused by strong rainfall that may cause flooding of areas where spatial management is not properly implemented. In addition climate change can lead to another serious problem - water shortages.

The next sector indicated in the SPA is "Spatial economy and urbanized areas". SPA indicates that climate change will lead to a reduction in the available space for a given type of conducted or planned activity, including due to the increased risk of flooding, increase of landslide risk, intensification of water and wind erosion processes, water deficit, elevation, as well as lowering groundwater level. Climate changes in the spatial context affect the whole complex of spatial development problems, which in extreme cases may generate social conflicts and limit development opportunities. Cities are directly threatened by three phenomena: intensification of the urban island of heat and strong downpours causing flooding and drought conducive to water deficit in cities. Precipitation like floods pose a threat to urban infrastructure through flooding, landslides and destruction of communication routes, buildings and property.

The aforementioned consequences of climate change for the water management of Polish cities indicate the need to conduct adaptation activities. The aim of this study is to: (1) assess the level of public water supply in Poland against the background of EU countries - a comparative analysis of existing sources Eurostat, (2) assess the involvement of Polish cities in adaptation to climate change in the context of countries EU - comparative analysis of the Eurostat index "Population covered by the Covenant of Mayors for Climate and Energy", (3) Assessment of the implementation of adaptation policy in the field of water management in Polish cities - a survey in 44 cities that are partners in the project "Let's feel into the climate!". 


\title{
Protection of Valuable Spaces, Local Cultural Heritage for Sustainable Development - The case of cultural parks in the Lodz region
}

\author{
JUSTYNA MICHALAK \\ University of Lodz \\ e-mail: justyna.miichalak@gmail.com \\ EWA BORYCZKA \\ University of Lodz \\ e-mail: ewa.boryczka@uni.lodz.pl \\ PIOTR RZEŃCA \\ University of Lodz \\ e-mail: piotr.rzenca@uni.lodz.pl
}

\begin{abstract}
Cultural parks are establishments that have been put in place in the Polish legislation to protect monuments and cultural landscape as well as maintain areas of distinguishing landscape merits including monuments typical of specific settlement and construction tradition. Cultural parks protect "space" as such with its natural components and man-made objects. This space is historically shaped by human interventions into a unique and original cultural landscape, a complex spatial structure including: courses (rivers, channels, roads, borders), planes (meadows, fields, water tanks, forests), and spots (natural objects, monuments). Such space provides relevant guarantee for the durability of growth. Under conditions of globalism, investment pressure and ad hoc benefits comprehensive protection of valuable cultural spaces becomes a special asset for sustainable development.
\end{abstract}




\title{
Activity of the Use and Water Protection Economics Section of the Polish Association of Environmental Economists and Natural Resources
}

RAFAŁ MItASZEWSKI

Cardinal Stefan Wyszyński University in Warsaw e-mail: r.milaszewski@uksw.edu.pl

\begin{abstract}
The objective of the paper is to present activities of the Section for the Use and Water Protection Economics of the Polish Association of Environmental and Natural Economists in 2007-2018. The performance of the Section will be discussed in three aspects, namely scientific-research, didactic and organizational. In the field of science and research, activities of the Section included the organization of six seminars and drawing up of expert opinions for two PAN committees. As part of the didactic activities, members of the Section gave lectures at post-graduate and master degree studies, among others at such universities as the Tadeusz Kościuszko University of Technology in Cracow and the Cardinal Stefan Wyszyński University in Warsaw. As part of the organizational activities of the Section, there are three research teams, i.e. the Water Management Investment Team at the Kraków University of Economics, Research Team on Water Supply and Water Management at the Białystok University of Technology and the Team for Cooperation with the International Water Association (IWA).
\end{abstract}


The spatial distribution of the JESSICA projects implemented in Polish municipalities

KAROL MROZIK

University of Life Sciences in Poznań e-mail: karol.mrozik@poczta.fm

\begin{abstract}
Regeneration - an integrated process of activities undertaken in the spatial, social and economic dimensions - should lead to the improvement of the living conditions of inhabitants of degraded urban areas. The European Union in 2007-2013 allocated financial resources for this purpose in the form of JESSICA initiative which is based on financial engineering mechanism. Experiences gained so far allow conclusions to be drawn that JESSICA is a highly financially-efficient instrument but, however, not always delivers the desired outcomes in the spatial and social sphere. The scope of projects often is limited to infrastructural investments and does not reflect the complexity of regeneration process. In the paper the authors try to assess a spatial distribution of the JESSICA projects which aims at finding relevant dependencies between spatial factors and selected characteristics of these projects. The study comprises five Polish regions which implemented the JESSICA initiative and all of the 161 projects executed by municipalities.
\end{abstract}




\title{
Low-Emission Economy Plans - Planning and Implementation Dilemmas. The case of cities of the Lodz Metropolitan Area
}

\author{
RAFAL MYSIALA \\ University of Lodz \\ e-mail: rmysiala@gmail.com \\ AgNIESZKA RZEŃCA \\ University of Lodz \\ e-mail: agnieszka.rzenca@uni.lodz.pl
}

\begin{abstract}
Our times are surely the urban age. Vast majority of global population live in cities and cities provide a breeding ground for new ideas and inventions. Undoubtedly, each city is an anthropogenic environment filled with multiple human activities and sometimes suffering from limitations resulting from them. In particular the exacerbating problems of poor air quality pose serious risk to the quality of life in a city. Contemporary cities should be able to successfully face the challenge and stimulate the development of low-emission economy. Low-emission Economy Plan is an instrument addressed to local authorities expected to respond to problems and needs of cities with this respect. This paper compares methodologies of drafting Low-emission Economy Plans and identifies their role in developing contemporary cities. Cities and towns of the Lodz Metropolitan Area have been selected for the case study as cities with industrial heritage mostly coping with environmental problems triggered by the stormy growth of textile industry in the 19th and 20th centuries as well as social and economic developments currently taking place in the Lodz region.
\end{abstract}




\title{
Sewage Treatment Plant Location Choice in Rural Commune by AHP Method \\ KATARZYNA OSZCZAPIŃSKA \\ Bialystok University of Technology e-mail: k.oszczapinska@doktoranci.pb.edu.pl \\ IWONA SKOCZKO \\ Bialystok University of Technology \\ e-mail: i.skoczko@pb.edu.pl
}

\begin{abstract}
The aim of the research was to identify the location of the local sewage treatment plant with the use of hierarchical multi-criteria analytical analysis: AHP (Analytical Hierarchy Process) taking into account technical, economic and social criteria. The analysis was carried out for the rural commune of Szumowo (Zambrów district), which since 2016 forms an agglomeration. According to the Functional and Utility Program, a sewage treatment plant with a capacity of $350 \mathrm{~m}^{3} / \mathrm{d}$ was proposed, taking into account 4 location variants with an area of approx. 1.3 ha.
\end{abstract}




\title{
Evaluation of Ecosystem Services on $\mathrm{CO}^{2}$ Absorption for the Regional Development
}

\author{
ALLA PAKINA \\ Lomonosov Moscow State University \\ e-mail: allapa@yandex.ru
}

\begin{abstract}
The "Assessment Report on Climate Change and Its Consequences on the Territory of the Russian Federation", issued by Federal Service on Hydrometeorology and Environmental Monitoring (Roshydromet), states that current climate change "has a serious impact on the socio-economic development of Russia». That's why transition to a low-carbon economy in Russian has to be the key direction of development towards sustainability. The analysis undertaken in our research allowed identify the territorial differentiation of the carbon absorption of the natural ecosystems and to compare it with the economy's carbon intensity at the districts of the Republic of Tatarstan, in order to move towards sustainable development.
\end{abstract}

The regional level of researches is the most suitable to make such study. The methodical approach based on the calculation of the natural ecosystems carbon absorption and its comparison to the carbon intensity of the regional economy were analyzed on the example of one of the most developed Volga regions - the Republic of Tatarstan.

The region was selected due to a number of reasons: economic (high level of economic development and diversified structure of the economy), environmental (location at the highly significant environmental region of the Volga river basin) and social (an inequality in the standard of living of the local population).

Widely known that changes in land use is a key factor of carbon emissions and absorptions balance at the regional level, and a carbon intensity of the regional economy can be considered as an indicator of economic efficiency. The carbon intensity of the regional economy we evaluated taking into account the carbon dioxide emissions from fuel combustion in the industrial sector. The data on fuel consumption was taken from official statistics sources. Since the required data are provided by national statistical agencies for administrative territorial units only, it was decided to make calculations on the scale of municipal districts of Tatarstan.

Taking into account a high level of diversification of the regional economy, different sources were used to analyze the land use's territorial structure and level of development: cartographic materials, space images, statistical compilations, state reports on environmental protection from the official web-sites of the regional and municipal administrations, etc.

The calculation of carbon dioxide absorbed by forest ecosystems and agricultural lands was carried out on the scale of forestry districts and arable lands respectively, due to statistical information in this field is also formed according the administrative territorial units. The calculations were made on the basis of data about the amount of carbon accumulated by different types of plant communities - for stands, litter and soils - in accordance to the methodical approach, based on 
recommendations of IPCC and adopted by Russian Ministry of Natural Resources and Environment. The total value of the absorbing capacity of forests, arable lands and pastures, and carbon deposits within the boundaries of the region were analysed with the Maplnfo program, which allows to determine the areas of positive and negative balance of carbon dioxide.

The land use structure in the region of the study is represented by a mosaic combination of industrial centers, including oil production and processing, agricultural lands, forests, water bodies, urban and rural lands, etc. The main source of $\mathrm{CO}^{2}$ emissions in the republic is the industrial enterprises, which are located in the districts with high share of transformed landscapes. They normally are deprived of forests and other natural vegetations and a potential of $\mathrm{CO}^{2}$ absorption is quite low. In agricultural lands $\mathrm{CO}^{2}$ emissions are not significant, and these areas are characterized by high carbon absorption. Analysis of land use structure and its difference by the districts of Tatarstan makes a basis to find correlation between the carbon intensity of the regional economy and the carbon absorption by the local ecosystems. According to our calculations, one hectare of agricultural crops in the Republic of Tatarstan absorbs from 2.15 to 4.9 tons of carbon dioxide per year. At the same time, one hectare of forest stands absorbs from 0.7 to 2.8 tons of $\mathrm{CO}^{2}$ per year. It means that agricultural fields are more effective as an absorber of carbon dioxide, but forests are more efficient as a carbon storage. Using the data on absolute values we compared the relative carbon intensity and carbon capacity per GRP unit for the Tatarstan districts.

All districts of Tatarstan can be divided into 3 groups by their potential to absorb $\mathrm{CO}^{2}$ :

1) districts with overrun of the limit (Nizhnekamsk, Zainsky, Naberezhnye Chelny and Kazan city);

2) districts on the edge of the limit (Yutazinsky, Almetyevsky, Zelenodolsk, Elabuga);

3) districts with high reserve of the limit (the rest).

Our research allowed to conclude, that the transition to a low carbon economy can be carried out by regulating land use patterns. The ratio of transformed and natural ecosystems plays a key role in economy carbon intensity. Natural landscapes such as forests, swamps and natural meadows absorb greenhouse gas emissions, while reducing environmental impacts. The extension of arable lands and following reduction of the forest areas has caused the carbon imbalance in regional land use. The digital map of the regional land use, based on space images and statistical data, allowed to evaluate the predominant types of landscape in the study area. Assessment of the carbon balance in the industrial and agricultural production and its regulation by increasing the natural areas can be the criterion of land use efficiency and sustainable regional development, especially in the region of economic growth such as Republic of Tatarstan.

The research was supported by the Russian Foundation for Basic Researches, the project 17-0200773 (Theoretical-methodological bases of sustainable development of Russia's regions (on example of the Volga region). 


\title{
The Level of Eco-Innovations in the EU Member States
}

JOLANTA PAKULSKA

Cardinal Stefan Wyszyński University in Warsaw e-mail: jolanta.pakulska@gmail.com

\begin{abstract}
The development of eco-innovation is a necessary 'tool' to permanently reduce human pressure on the environment and efficient use of dwindling natural resources. Increasingly, however, literature emphasizes the role of eco-innovation as one of the basic factors of sustainable development. The article presents issues concerning eco-innovation, its later part analyses the capabilities and limitations of their introduction to the economy of selected European Union countries, including Poland. The aim of the study is to systematize the knowledge of environmental investment, and to indicate the possibility and necessity of their continuous development. The methodology used is based on an analysis of available literature and analysis of statistical data.
\end{abstract}




\title{
Ecological Innovations as an Element of the Organization Strategy
}

\author{
JOLANTA PAKULSKA \\ Cardinal Stefan Wyszyński University in Warsaw \\ e-mail: jolanta.pakulska@gmail.com \\ MAŁGORZATA RUTKOWSKA \\ Wroclaw University of Science and Technology \\ e-mail: malgorzata.rutkowska@pwr.edu.pl
}

\begin{abstract}
The aim of the article is to discuss the importance of eco-innovation for corporate social responsibility. In the first part shows the essence of the corporate social responsibility and an overview of the most important international initiatives for the promotion of corporate social responsibility. Next discusses CSR in Poland. In the next part of the article indicated the essence of eco-innovation in terms of corporate social responsibility.

In the article a descriptive method. It consisted in extracting and identifying a specific phenomenon, what is the impact of corporate social responsibility initiatives used for eco-innovation. In the further part of the development of applied comparative analysis, which indicated any changes and irregularities and deviations from the accepted standards. Test results are presented in tabular layout.
\end{abstract}




\title{
Comparison of water footprint of Poland and Ukraine
}

DAMIAN PANASIUK

Cardinal Stefan Wyszyński University in Warsaw e-mail: d.panasiuk@uksw.edu.pl

RAFAt MIŁASZEWSKI

Cardinal Stefan Wyszyński University in Warsaw

OLENA SUDUK

National University of Water and Environmental Engineering, Rivne

PETRO SKRYPCHUK

National University of Water and Environmental Engineering, Rivne

\begin{abstract}
The water footprint is an instrument that allows you to link the consumption of water resources with the consumption of goods. The blue water footprint shows the consumption of water for the production of goods, green - use in agriculture and forestry, and gray - the amount of water necessary to assimilate pollution. Poland and Ukraine are countries that differ in climate. The northwestern part of Ukraine has a climate similar to Poland (temperate continental with a rainfall of $600 \mathrm{~mm}$ /year), while the south of Ukraine is the steppe with warm continental and ocean climate with a rainfall of $300 \mathrm{~mm} /$ year. This affects the greater use of water in Ukrainian agriculture. The green footprint of Ukraine $\left(2302 \mathrm{~m}^{3} / \mathrm{cap} / \mathrm{yr}\right)$ is 2 times higher than in Poland $\left(1121 \mathrm{~m}^{3} / \mathrm{cap} / \mathrm{yr}\right.$ ). As a result, the total water footprint of Ukraine $\left(2881 \mathrm{~m}^{3} / \mathrm{cap} / \mathrm{yr}\right)$ likewise exceeds the total water footprint of Poland (1503 $\mathrm{m}^{3} / \mathrm{cap} / \mathrm{yr}$ ). Analysis of "virtual water" indicates net export of green water with food from Ukraine $\left(282 \mathrm{~m}^{3} / \mathrm{cap} / \mathrm{yr}\right.$ ), while net import of green water with food to Poland (147 $\mathrm{m}^{3} /$ cap/yr).
\end{abstract}


Impact of rivalry and excludability on Individual Social Responsibility in the context of transport behaviour

MONIKA PARADOWSKA

University of Wroclaw

e-mail: monika.paradowska@uwr.edu.pl

\begin{abstract}
Purpose: The purpose of the paper is to examine the impact of modifications of the levels of rivalry and excludability in the access to different elements of urban transport systems on the required changes in the transport behaviour and the development of Individual Social Responsibility (ISR) in transport activities.

Methodology/approach: In the first part of the paper the literature review is presented in order to give the theoretical background for the concepts of the sustainable urban mobility, the sustainable transport behaviour, as well as for the concept of ISR. In the second part, a survey results among urban transport users are presented and discussed in order to realise the purpose of the article.

Findings: Based on the survey results, a real impact of sustainable urban mobility tools based on changes in the levels of rivalry and excludability is analysed on the required change in the transport behaviour in the context of the necessity of or willingness to be more sustainable in daily urban trips.

Originality/value: In the paper, the concept of ISR in transport activities is discussed, and the compatibility between the transport behaviour and the awareness of the impact of personal transport behaviour is verified.
\end{abstract}


Benefits of including the concept of corporate social responsibility in the strategy of transport sector companies

\author{
BARBARA PAWŁOWSKA \\ University of Gdańsk \\ e-mail: bpawlowska@ug.edu.pl
}

\begin{abstract}
The economy is governed by constant change, and business models and strategies of the enterprises often become outdated before they are implemented. Such circumstances of the modern world force entrepreneurs to use creative thinking and non-standard solutions. A change is present in almost all business areas - starting from production, through distribution, marketing, and sales, to operational management. It is a commonly accepted permanent standard of current times. The contemporary course of socio-economic development on the international arena is outlined by Agenda 2030, adopted in 2015, where the idea of sustainable development is the core. One of the tools for implementing sustainable development is the concept of corporate social responsibility (CSR). The aim of the article is to identify the benefits of incorporating CSR strategies into the business model of transport sector companies - from visions and missions, through strategic objectives, policies and programs, and ending with procedures. It is supposed to improve efficiency and to bring stable results, which will become a source of competitive advantage in the transport sector.
\end{abstract}


Impact of natural and anthropogenic factors on the water resources of the Wielkopolsko-Kujawski Lake District

ADAM PIASECKI

AGH University of Science and Technology e-mail: adm.piasecki@gmail.com

\begin{abstract}
Lakes are an inseparable element of the early post-glacial landscape of northern Poland. Although from a geological point of view they are only an episodic phenomenon, they constitute a very important element of the geographical environment.

The aim of the work was to analyze the natural and anthropogenic factors shaping the water resources of the Wielkopolsko-Kujawski Lake District. The work involved analysis of cartographic material from different periods and remote sensing data, IMGW PIB data, as well as a number of studies regarding the analyzed area, significant from the perspective of the investigated topic.

As a result of the analysis, significant changes in water resources and lake surface were found. The registered changes were in most cases negative. The largest transformations occurred in lakes with small areas (less than 100 ha). Lakes from this group have reduced their area by as much as 40 percent (for example Suszewskie Lake). Highlighted was also the spatial diversity of the changes. The presented results clearly indicate the progressing degradation and accelerated disappearance of lakes in this part of Poland.
\end{abstract}




\title{
Production of phosphate fertilizers - comparison of the conventional method with the Best Available Technique (BAT)
}

KATARZYNA PIEKLARZ

Lodz University of Technology e-mail: katarzyna.pieklarz@edu.p.lodz.pl

\begin{abstract}
Over the last decade, there has been an increase in the use of mineral fertilizers, including phosphate fertilizers. This is due to the decrease in the livestock population, and thus to the decrease in organic fertilization. However, it is important to realize that fertilizer production processes can pose a serious threat to the environment. Already at the stage of pre-treatment of phosphoric raw materials there are emission of many chemical compounds, such as: hydrogen sulphide, aliphatic hydrocarbons and organic sulphides and disulphides.

Bearing in mind the harmful effects of released substances, radical changes in technology are observed in the fertilizer industry.

The paper presents the current state of knowledge on the technology of producing phosphate fertilizers including potential sources of pollution, on the example of the production of simple SSP superphosphate. In addition, alternative pro-environmental solutions based on the BAT guidelines will be presented.
\end{abstract}


The Concept of a Climate Resilient Economy from the Perspective of Local Communities

\author{
DARIUSZ PIEŃKOWSKI \\ University of Life Sciences in Poznan \\ e-mail: pienkow@up.poznan \\ WOJCIECH ZBARASZEWSKI \\ West Pomeranian University of Technology \\ e-mail: wzbaraszewski@zut.edu.pl
}

\begin{abstract}
The concept of a climate resilient economy appeared particularly intensively in economic considerations in 2015 in the context of the Paris Agreement under the climate conference. However, the very concept of resistance emerged in the 1970s in the ecological research and was also widely considered from the perspective of socio-economic development. The paper seeks to indicate the importance of this concept for socio-economic considerations from the perspective of the economies of local communities. The paper also presents the objectives of the European Union policy related to the creation of climate resilient economies. It also analyses the examples of such an approach to local economies and the possibilities of creating climate resilient economies in Poland.
\end{abstract}




\title{
Non-renewable natural resources as the key factor in civilizational development
}

TADEUSZ PINDÓR

AGH University of Science and Technology e-mail: tpindor@zarz.agh.edu.pl

\begin{abstract}
The paper provides an overview based on results of qualitative research into transformations of the structure of the global economy. The main purpose of the paper is to show the importance of nonrenewable natural resources as the key factor, beside entrepreneurship and innovativeness, of civilizational development. The paper characterises raw materials and consumables acquired from environmental resources, i.e. nanomaterials as well as critical elements and raw materials as the basis for the new technologies and new products. It also defines the concept of reindustrialisation in conditions of creating and implementing the principles of permanent and sustainable development. In particular, it indicates and analyses the factors that enable transition to a lowemission economy, and in the future to a circular economy. The paper characterises contemporary changes in the economic map of the world by identifying new growth and competitiveness poles. Against this background, the civilizational challenges facing the Polish economy have been presented.
\end{abstract}




\title{
Determinants of the circular economy development for plastics
}

KRZYSZTOF POStUSZNY

AGH University of Science and Technology e-mail: kposlusz@zarz.agh.edu.pl

\begin{abstract}
Idea of circular economy is a natural direction of the development of environmentally oriented management. It is assessed that $95 \%$ of plastic packaging materials, valued at 100 bill. USD is lost shortly after first use. Closing of a production-use loop can be cost effective and can bring reduction of environmental burden. Closed economy in plastics has also far reaching consequences: stimulation structural changes in industry, new value chains, changes in technologies and investment in raw materials as well as changes in the international trade. In the paper some forecasts and assessments of circular economy consequences for local producers and users in plastics are presented and discussed on the example of main plastics: PE, PP, PVC, EPS and PET.
\end{abstract}


Directions of using municipal sewage sludge in the European Union conclusions from the analysis of statistical data

\author{
KSYMENA ROSIEK \\ Cracow University of Economics \\ e-mail: ksymena.rosiek@uek.krakow.pl
}

\begin{abstract}
Poland has great achievements in water and sewage management. In the last fifteen years, a lot of water and sewage infrastructure were created, including sewage treatment plants. The disposal of sewage sludge was not considered an indispensable element of closure of the wastewater treatment process. The main way to handle municipal sewage sludge was to bury it on the landfills or use it for agricultural and reclamation purposes. The European Union's requirements go towards a comprehensive solution of waste issues and closing down all processes in the context of a circular economy. Poland faces new challenges and the tougher standards regarding the use of sludge. The experiences of other countries can and should be taken into consideration regarding changes in the management of sewage sludge. The aim of the article is to indicate possible directions for sewage sludge management in Poland and selected New European Union Members Countries on the basis of observed trends in the countries of the Old Union.
\end{abstract}


Insurance awareness in the field of weather risks

ELEONORA RATOWSKA-DZIOBIAK

University of Lodz e-mail: eleonora.ratowska@uni.lodz.pl

\begin{abstract}
The aim of the article is to assess the changes in insurance awareness of entities on the Polish market. The studies carried out indicate that from the point of view of the client, the attractive price combined with comprehensive service play an important role. The interviewees emphasize that the inclusion of new threats and matching the offer with the needs of the buyer may significantly affect the demand for insurance services. Consumer interest in protective products in the area of weather risks may also depend on innovative solutions in the manner of their distribution (including the mutual insurance system).
\end{abstract}




\title{
All for one and one for all? External effects of water supply as provisioning service of ecosystems
}

\author{
MAtGORZATA STĘPNIEWSKA \\ Adam Mickiewicz University in Poznan \\ e-mail: stepniew@amu.edu.pl \\ ANDRZEJ MIZGAJSKI \\ Adam Mickiewicz University in Poznan \\ e-mail: andrzej.mizgajski@amu.edu.pl
}

\begin{abstract}
The aim of the research is to investigate social perception of external effects of the functioning of the protection zone of Mosina-Krajkowo water intake in the Greater Poland voivodeship. The Mosina-Krajkowo water intake constitutes the source of potable water for 521 thousand inhabitants of Poznań agglomeration. High exposure to human pressure constituted a decisive factor of the introduction in 2012 of legal prohibitions, orders and limitations in force within the indirect protection zone of the intake. The zone is formed by the area of $56 \mathrm{~km}^{2}$ within Mosina, Puszczykowo and Brodnica communes. The introduced restrictions may be treated as external effects of water supply for the whole agglomeration influencing local community within the protection zone.

In order to recognize the opinion of the local community on environmental, social and economic external effects, we conducted face-to-face interviews separately with a sample of 52 inhabitants, 37 farmers and 5 officers representing local administration. Next we juxtaposed these opinions with social and economic situation within the area subject to prohibitions, orders and limitations basing on statistical data.

The interviews demonstrated that the inhabitants treat as limitations these restrictions and changes which in fact result from improving environmental standards of the country, in particular in the area of farming. What is more, within the water intake protection zone, general standards are more rigorously enforced. The results of the study allowed us to provide recommendations to decisionmakers towards the strengthening of public education and information concerning water intake protection.
\end{abstract}


Environmental education vs. punishment - an issue of protection of environment

DIANA SZWEJSER

University of Wrocław e-mail: diana_sz@gazeta.pl

\begin{abstract}
Supplying former peoples' needs pressured them to exploit natural resources and to transform it. Down the years hazardous industrial activities rendered that countries instituted environmental protection regulations. A part of this regulations is legal liability because of breaching the law. Because there are so many legal sanctions, more and more we can hear that it is better to point people that they have to protect environment. This is a serious matter because in my opinion an ounce of prevention is worth a pound of cure.
\end{abstract}




\title{
Ecological modernization - the issue of efficiency
}

PAULINA SZYJA

Pedagogical University of Kraków e-mail: paulinaszyja@wp.pl

\begin{abstract}
The issue of ecological modernization is gaining importance today in the context of green economy programs, or the creation of a low-carbon economy and circular economy. In all three aspects of the operationalization of the concept of sustainable development, the issue of efficiency plays an important role. Accordingly, it can refer to energy efficiency, use of raw materials / materials and waste, etc. The economic and environmental benefits are no less important.

The aim of the study is to present the theoretical aspects of ecological modernization in the context of efficiency related to innovative solutions in agriculture and industry.
\end{abstract}




\title{
Circulation of matter in the natural and anthropocentric perspective
}

\author{
JERZY ŚLESZYŃSKI \\ University of Warsaw \\ e-mail: sleszynski@wne.uw.edu.pl
}

\begin{abstract}
The closed circuit economy is a term that is currently making a booming career. It occurs in the statements of environmental activists, in the speeches of politicians, and above all in the documents setting out the strategies and directions of policy development for individual countries and the entire European Union. The prevailing belief is that a sustainable development strategy easily absorbs the idea of a closed circuit and its specific recommendations, and in any case that it is consistent with the paradigms of sustainable development.
\end{abstract}

The aim of the presentation is to present and analyze differences in the interpretation of the closed circuit in the natural environment and in the economy. The first part will discuss the functioning of the biosphere, which is the largest ecosystem known to us, and at the same time the living environment of all living organisms, including humans. The circulation of matter and the flow of energy are two phenomena whose interpretation in the biosphere, taking into account biogeochemical cycles and laws of thermodynamics, allows to understand how the circulation of matter in the natural system takes place.

Even preliminary comparisons indicate that neither small-scale recycling nor closed-loop design in the world economy meet the basic requirements that are always present in natural cycles. The basic differences are connected with the energy sources used and the way energy is absorbed, and result from the lack of systemic dependencies and connections between autotrophic organisms, heterotrophic organisms and reducers, also known as decomposers.

The conclusion made from the comparisons and considerations is not optimistic. The closed cycle is a peculiar feature of the biosphere shaped during over 3 billion years of evolving life on Earth through constant changes and ecosystem adaptations. The managerial anthropocentrism must cause that the created closed circuits will be exposed to relative isolation from the natural environment and will require a constant supply of energy produced by man. Indeed, any proposal to create a closed circuit due to the discretionary and wishful nature of such ventures will require a separate and in-depth analysis that will allow to determine whether projects are actually advocating lower consumption of matter and energy. A separate analysis should examine whether a given closed circuit really contributes to sustainable development, which must also take into account at the same time the natural, economic and social aspects of the proposed solutions. 
The development of road transport - opportunities and threats to the environment and society

\author{
MARIUSZ TRELA
}

AGH University of Science and Technology e-mail: mtrela@zarz.agh.edu.pl

\begin{abstract}
Economic development on the one hand is implemented to a large extent due to the development of road transport through increased transport work (in the case of commercial vehicles) on the other hand it is economic development that allows the development of road transport through the development of technology, while increasing the income and expectations of societies. These mutual relations generate both opportunities and threats to the environment and society resulting from the development of road transport.

The purpose of the article is to identify and analyze the opportunities as well as the risks posed by the development of road transport for the environment and society. The analysis covered issues related to environmental protection, supplementing them with technical and social issues. Individual aspects were identified and analyzed within these issues and each time they were classified as an opportunity or a threat. Lessons were learned about the direction of road transport development from a social point of view, taking into account the principles of sustainable development.
\end{abstract}


The impact of energy consumption, foreign direct investment, trade openness, corruption, and GDP on carbon dioxide emissions in Poland

\author{
DOROTA WAWRZYNIAK \\ University of Lodz \\ e-mail: dorotawawrzyniak@10g.pl
}

\begin{abstract}
The study investigates the impact of energy consumption, foreign direct investment, trade openness, corruption, and GDP on carbon dioxide emissions in Poland for the period of 1995-2014. The estimation results support the presence of the inverted U-shaped relationship between GDP and $\mathrm{CO}^{2}$ emissions postulated by the Environmental Kuznets Curve. The findings indicate also a considerable impact of energy consumption on $\mathrm{CO}^{2}$ emissions during the study period. Out of foreign direct investment, trade openness, and corruption, only the last variable determines carbon dioxide emissions. The emissions decline with corruption decrease, but the effect is relatively small. Generally, the findings suggest that in order to improve environmental quality Poland should undertake actions aimed at implementing a low-carbon economy with an emphasis on energy efficiency. Moreover, corruption decrease may help to reduce the pollution.
\end{abstract}


Causes and extent of soil acidification resulting from agricultural activity thoughts in the context of good agricultural practice

\author{
MIROStAWA WITKOWSKA-DĄBROWSKA \\ University of Warmia and Mazury in Olsztyn \\ e-mail: m.witkowska@uwm.edu.pl
}

\begin{abstract}
The research intended to evaluate the extent of soil acidification caused by farming in districts across the Province of Warmia and Mazury, Poland. Warmia and Mazury are considered to represent an agricultural region, and agriculture is this domain of economy that has a strong impact on the natural environment, including soils. Consequently, other resources are exposed to strong influences as well. Nearly the whole territory of Poland lies in the so-called vulnerable area, while the Province of Warmia and Mazury is situated in the immediate vicinity of the Baltic Sea, which makes it worthwhile to explore the problem how the effects produced by agriculture on soil acidity are distributed spatially. The article attempts to identify the spatial distribution of soil acidification and the needs for liming in the studied areaon in Olsztyn. The data originated from the Bank of Local Data and the Provincial Inspectorate of Environmental Protecti in Olsztyn.
\end{abstract}


Foreign Direct Investment and the Environment

MichAt WOJTASZEK

Warsaw University of Life Sciences e-mail: michal_wojtaszek@sggw.pl

\begin{abstract}
FDI and the environment involves international businesses and their interactions and impact on the natural world. Over the last few decades, increasing levels of environmental degradation have been recorded and have been claimed to be particularly attributable to globalization and the widespread increase of economic activities, in particular Foreign Direct Investments. There are needs to set environmental policy and to monitor progress towards meeting society environmental goals. Policies created that attract innovative and environmentally conscious technological advancements have been stated as a great way to encourage increase in the abundance of environmentally friendly foreign direct investments. Foreign direct investments allow for the chance of compromise and collaboration between policies of negotiating countries which brings the opportunity for new perspectives on green innovation.
\end{abstract}


How important urban and post-industrial habitats are for ecosystem services?

GABRIELA WOŹNIAK

University of Silesia in Katowice e-mail: gabriela.wozniak@us.edu.pl

EDYTA SIERKA

University of Silesia in Katowice

AGNIESZKA BŁOŃSKA

University of Silesia in Katowice

WOJCIECH BIERZA

University of Silesia in Katowice

TERESA NOWAK

University of Silesia in Katowice

AGNIESZKA KOMPAŁA-BĄBA

University of Silesia in Katowice

ANNE WHEELER

Aston University, Birmingham, UK

\begin{abstract}
The integrated natural and human models for sustainable management can used to understand the dynamics of ecosystems in order to simulate and evaluate different management scenarios in relation to biodiversity and ecosystem services. There is a need for the increasing understanding of the role of biodiversity and ecosystem service identification as important factors influencing the dynamics of ecosystem and sustainable management scenarios. In ecological restoration the biggest challenge is to find a general consensus of suitable biodiversity indicators and economically viable measures which will produce multiple social and ecologically guided environmental benefits. In an effort to restore sites disturbed by industrial activities, restoration projects should involve ecologically based methods and approaches which will be able to fulfill many stakeholders' expectations for sustainable development and human well-being.
\end{abstract}




\title{
The „Eco” Philosophy in Visual Communication Design - Visible / Invisible Signs, intuition / impression / perception
}

\author{
ANNA WRZESIEŃ \\ Strzemiński Academy of Art Łódź \\ e-mail: annawrzesien@gmail.com
}

\begin{abstract}
These images, which are more or less clear, appear and connect with each other, are essential elements of thinking.
\end{abstract}

R. Arnheim

This paper concerns relations between two issues. And it is a reflection on what I see, what I understand and what I worry about. The first issue is ecology, the second is the sign.

\section{ECOLOGY / SIGN = ECOLOGICAL SIGNS}

From a graphic designer's and an academic teacher's point of view, fundamental questions arise... What do these two issues have in common and what is the difference between them?

Are we conscious recipients of graphic signs? How should eco-graphic sign design be taught?

Ecology is the scientific study of the structure and functioning of nature. It explores interactions between organisms and their environment and the relationships between these organisms.

The word ecology is at the top of the whole group of words that are derived from it. It is a representative of a large family of words whose meanings are similar but each of them is unique. . . therefore, each is a separate organism. In the process of building visual communication and shaping visual expression, one of the most important factors to analyze is legibility. . . and also the balance between aesthetic quality and verbal quality. Ecology is a process thanks to which our planet is regaining (or should be regaining) its balance. Is it possible for symbols, signs and eco-signs to remain unchanged? Or should they evolve along with the process? Should they be more legible? Or perhaps there is no need for new ones?

To quote the aforementioned Rudolf Arnheim: "(. . ) Designers of trademarks cannot count on the powerful social forces that Hitler wielded. Their task is also extremely complicated because of the fact that in most cases the signs that they create are not understandable by themselves. Contemporary taste and style make us associate effective entrepreneurship with clear, reduced to a minimum forms, and the chaos and haste of modern life require stimuli with immediate effect. The problem is that symbols with a high degree of abstraction are not suitable for clearly indicating their designations, yet the purpose of advertising activities is to identify a given company, brand, institution or idea".

Let's imagine that the "idea" is ecology. So, the question is what can make it

\section{RECOGNIZABLE, UNIVERSAL, LASTING...?}




\title{
When tree stands can be cut? - case study of carbon accumulation and timber production
}

\author{
EMILIA WYSOCKA-FIJOREK \\ Forest Research Institute \\ e-mail: e.wysocka-fijorek@ibles.waw.pl
}

\begin{abstract}
Central task of the report is choose the age at which stands of growing timber should be harvested. The choice determines how long each stand must continue to earn interest, and also determines the size of the total inventory that must be to sustain the annual harvest. It is a problem that calls for analysis of biological as well as economic relationships over time and has intrigued economists for more than two centuries. The method of determining the rotation age depends primarily on the objectives and management practices (e.g. timber production, carbon accumulation), which determine the optimal age of trees and stands for felling. It includes the methodological basis of optimization of the rotation age of stands due to the maximization of the accumulation of timber and carbon production in the tree stands.

The report analyses the timber and carbon production function depending on rotation age, growth, cost and other characteristics of forest, as well as the costs of land. The prerequisite for achieving the economic optimum of the rotation age of a stand is to balance the current increase in the total timber production value (growth and yield) and the value of opportunity costs from delaying cutting till the next year. This report demonstrates how this economically optimum rotation age can be calculated, and how it varies according to the biological growth and economic parameters of the forest.
\end{abstract}


Forestry Social Responsibility Concept

\author{
EMILIA WYSOCKA-FIJOREK \\ Forest Research Institute \\ e-mail: e.wysocka-fijorek@ibles.waw.pl \\ PIOTR KOMOROWSKI \\ Forest Research Institute \\ e-mail: piotr.komorowski@olsztyn.lasy.gov.pl
}

\begin{abstract}
The State Forests National Forest Holding is an important entity operating in a specific social environment. Striving to realization and achieve statutory goals and related to this maintaining appropriate relations with the environment requires undertaking many, often large-scale activities with a beneficial social impact.

In the space of years, many standards and concepts have been developed that point to the special role of social aspects that complement the implementation of the core business objectives such as multiplying capital and obtaining the highest income. One of them is the concept of corporate social responsibility. The beginnings of this concept date back to the end of the 19th century, and the main development took place in the second half of the twentieth century, initially in the United States, then gradually in Europe.
\end{abstract}

The basic division of social responsibility objectives includes objectives: ecological, economic and social. According to the approach consistent with the concept of corporate social responsibility, transparency in the field of responsibility does not only mean that economic organizations (business organizations) meet all formal and legal requirements. It is also necessary to increase investments in human resources, to protect the environment and relations with stakeholders who may have a real impact on the efficiency of their business operations and their innovation. Expenditures of this kind should be treated as an investment and source of innovation, not as an expense. Transparency in the field of corporate social responsibility has a positive impact on the image of entities based on this concept. The concept of corporate social responsibility is closely related to the idea of sustainable development. Social responsibility requires a strategic and long-term approach, which should be implemented in a climate of social dialogue and seeking solutions that are beneficial for all interested parties. Corporate social responsibility in the context of the idea of sustainable development requires development, refinement, redefinition and searching for appropriate relationships and conditions based on appropriately developed measures and indicators.

The possibilities of applying the principles of corporate social responsibility to the specifics of the organizational activities of The State Forests National Forest Holding they are not explicit and require conducting research that was undertaken during the implementation course of this elaboration. 
The possibility of using considered a weed Impatiens parviflora DC. as a source of valuable antioxidants

\author{
JOANNA ZIELONKA-BRZEZICKA \\ Pomeranian Medical University in Szczecin \\ ANNA NOWAK \\ Pomeranian Medical University in Szczecin \\ ADAM KLIMOWICZ \\ Pomeranian Medical University in Szczecin \\ MAGDALENA TKACZ \\ Pomeranian Medical University in Szczecin \\ e-mail: m.tkacz1994@gmail.com \\ DANUTA MARTYNIUK \\ Pomeranian Medical University in Szczecin \\ e-mail: danutamartyniuk8@gmail.com
}

\begin{abstract}
Introduction: Impatiens parviflora DC. is classified in Poland as an invasive plant, which control requires a lot of time and financial outlay. The possibility of using it as a raw material for pharmaceutical purposes would optimize the costs caused by preventing propagation of Impatiens parviflora DC.

The aim of the study was to evaluate the antioxidant properties of dried impatiens herb.

Materials and methods: Antioxidant activity of dried Impatiens parviflora DC. extracts was evaluated using the following methods: DPPH, FRAP and Folin-Ciocalteu.

Results: The antioxidant activity evaluated by the $\mathrm{DPPH}$, ranged from $0,43 \pm 0,03$ to $3,90 \pm 0,03 \mathrm{mg}$ trolox/g of raw material, by the FRAP method ranged from $3,10 \pm 0,12$ to $13,89 \pm 0,89 \mathrm{mg}$ FeSO4/g of raw material, by the Folin Ciocalteu method $-1,74 \pm 0,37$ to $10,42 \pm 0,43 \mathrm{mg} \mathrm{GA} / \mathrm{g}$ of the raw material.
\end{abstract}

Conclusions: The extracts of Impatiens can be a source of antioxidants. 
DOI 10.18778/8142-413-4.01

e-ISBN 978-83-8142-413-4 
